\title{
The human crystallin gene families
}

\author{
Graeme Wistow
}

\begin{abstract}
Crystallins are the abundant, long-lived proteins of the eye lens. The major human crystallins belong to two different superfamilies: the small heat-shock proteins (a-crystallins) and the $\beta \gamma$-crystallins. During evolution, other proteins have sometimes been recruited as crystallins to modify the properties of the lens. In the developing human lens, the enzyme betaine-homocysteine methyltransferase serves such a role. Evolutionary modification has also resulted in loss of expression of some human crystallin genes or of specific splice forms. Crystallin organization is essential for lens transparency and mutations; even minor changes to surface residues can cause cataract and loss of vision.

Keywords: Crystallins, Lens, Cataract, Evolution, Pseudogene, Heat-shock, Enzymes
\end{abstract}

\section{Background}

Crystallin is a functional term that originated as a description of the highly abundant soluble proteins of the 'crystalline' (clear) vertebrate eye lens [1,2]. Crystallins fill the hugely elongated, terminally differentiated fiber cells of the lens and must survive without turnover throughout life while maintaining transparency and the molecular organization required for the refractive properties of the lens. As such, the complement of crystallins in the lens has been peculiarly sensitive to evolutionary pressures and has shown remarkable adaptation in different vertebrate lineages [1]. As a result, some crystallins have very restricted distributions among species. However, there is a core set of three originally identified classes, the $\alpha$-, $\beta$ - and $\gamma$-crystallins, that must have arisen in early aquatic ancestors, are widespread among vertebrates, and account for most of the protein content of the human lens. These three classes were defined mainly by the sizes of oligomers they form, from very large $\alpha$-crystallin multimers (on the order of $500 \mathrm{kDa}$ ), through dimer- to octamer-sized $\beta$-crystallins (approximately 45 to $180 \mathrm{kDa})$ to $\gamma$-crystallin monomers $(20 \mathrm{kDa})$ [3]. Once sequence data were obtained, it became clear that the multimeric $\beta$ - and monomeric $\gamma$-crystallins are in fact part of the same $\beta \gamma$-crystallin superfamily. Although crystallins were originally identified in the lens, they also have roles

\footnotetext{
Correspondence: graeme@helix.nih.gov

Section on Molecular Structure and Functional Genomics, National Eye Institute, Bg 6, Rm 106, National Institutes of Health, Bethesda
} MD20892-0608, USA in other tissues and have superfamily relationships with other proteins. Indeed, throughout evolution, crystallins seem to have been recruited from existing proteins whose structure and other properties happened to suit them for the new role in lens [4].

By analogy to the lens, "crystallin" has also been used to describe abundant soluble proteins in the cornea, another transparent tissue [5-7]. However this review will focus only the human genes for proteins that are highly abundant in the lens and have crystallin as part of a HUGO Gene Nomenclature Committee (HGNC) designation or a widely used name.

A useful resource to search for expressed sequence tag (EST) data for crystallins (and other eye-expressed proteins) is NEIBank (http://neibank.nei.nih.gov) [8] and the accompanying eye-centric genome browser, EyeBrowse (http://eyebrowse.cit.nih.gov/) which displays expression and disease gene information for eye genes of human and several other species. Details of gene organization and splice patterns described in this review can be conveniently viewed using EyeBrowse or the original UCSC browser (http://genome.ucsc.edu/).

\section{CRYAA and CRYAB: genes for a-crystallins}

In humans (and apparently most terrestrial vertebrates) there are two $\alpha$-crystallin genes, CRYAA and CRYAB, encoding $\alpha \mathrm{A}$ - and $\alpha \mathrm{B}$-crystallins [2,9]. They are located in different chromosomes (21 and 11), but they are closely related in sequence and gene structure and are clearly the result of an ancient gene duplication. Both
C Biomed Central

(c) 2012 Wistow; licensee BioMed Central Ltd. This is an Open Access article distributed under the terms of the Creative Commons Attribution License (http://creativecommons.org/licenses/by/2.0), which permits unrestricted use, distribution, and reproduction in any medium, provided the original work is properly cited. 


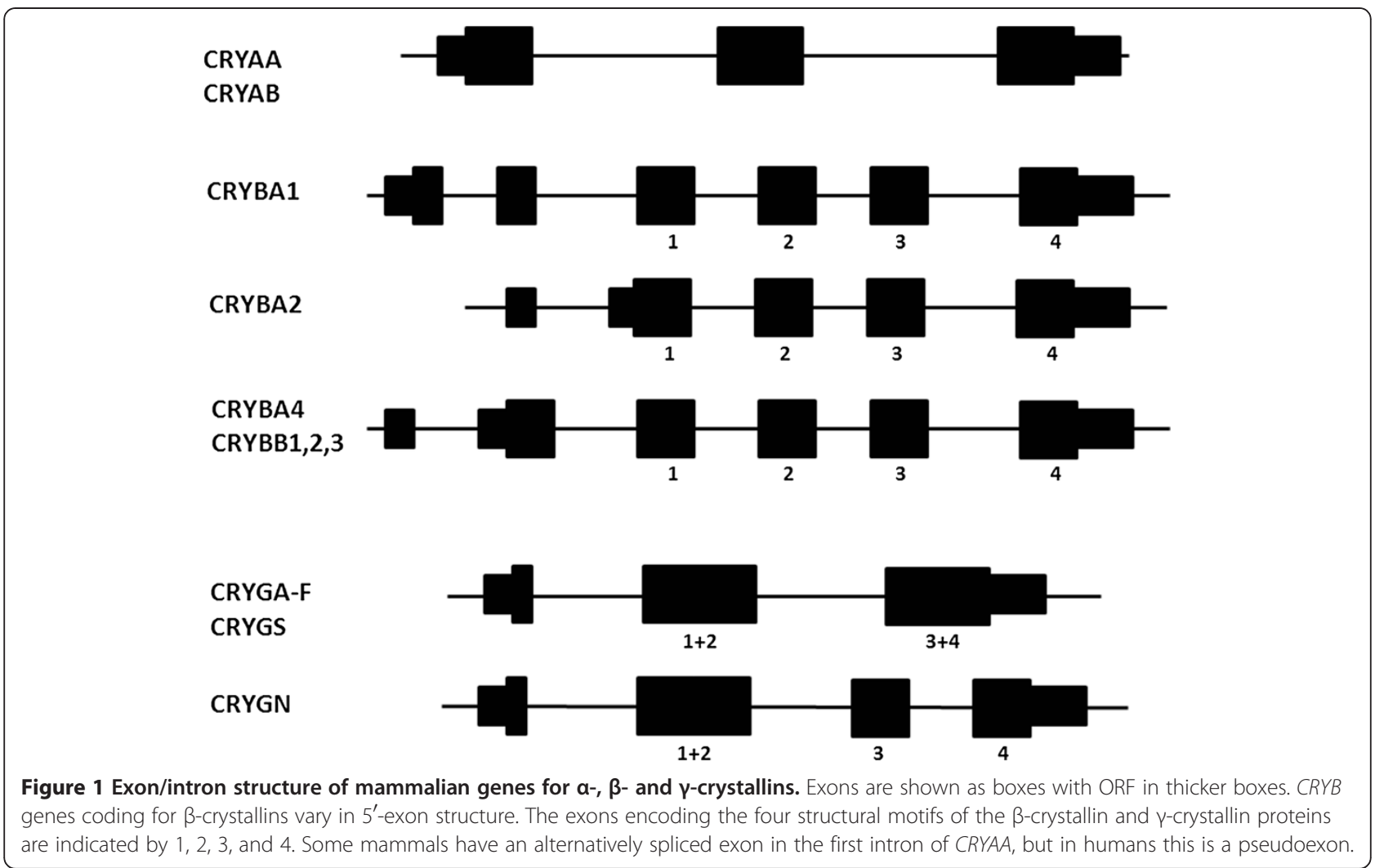

genes are 3 to $4 \mathrm{~kb}$ long with three exons (Figure 1). They have open reading frames (ORFs) of $173(\alpha \mathrm{A})$ and 175 codons $(\alpha B)$, corresponding to subunit sizes of approximately $20 \mathrm{kDa}$, and the two proteins are $54 \%$ identical in sequence. Ancestrally, the gene for $\alpha \mathrm{A}$ crystallin had three exons, and this is reflected in many species from fish to birds. However, during the evolution of the mammalian lineage, there was an innovation with the addition of an alternatively spliced exon, giving rise to a larger protein product ( $\alpha$ Ains) [10]. The insert exon' is retained in many species, particularly rodents. In primates, this alternative splice form was abandoned, but the remnants of the insert exon remain in human CRYAA as a pseudoexon [11]. While the sequence is no longer spliced into mature mRNA, it is largely intact, raising the interesting possibility that mutation could restore splicing and perhaps lead to a novel cataractogenic defect.

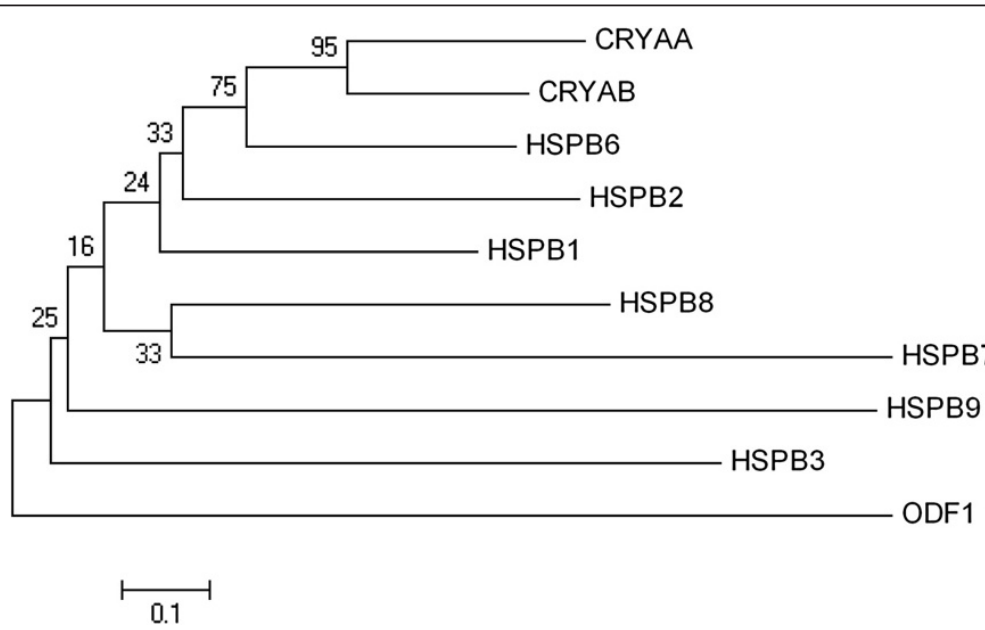

Figure 2 Phylogenetic tree of the human sHSP gene family. Sequences were extracted from the UCSC web browser. Translated ORFs were aligned and neighbor-joining trees were constructed using MEGA4 [15]. 


\section{Superfamily relationships}

$\alpha$-crystallins belong to the superfamily of small heat-shock proteins (sHSP) produced by even older duplications [12] (Figure 2). In humans, there are ten genes for sHSPs $[13,14]$, and $C R Y A A$ and $C R Y A B$ also have the alternative systematic (but not widely used) names HSPB4 and 5 . The tenth member has the HUGO name ODF1 [13]. Since the $\alpha$-crystallins are the archetypes of the superfamily, the core-conserved region of the sequence for all these proteins is referred to as the $\alpha$-crystallin domain [9]. Indeed, two of the non-crystallin members of this superfamily, HSPB6 and HSPB9, have 'alpha-crystallin-related' as part of their HUGO designation. Although the two $\alpha$-crystallin genes are not themselves linked, CRYAB is located head-to-head (adjacent $5^{\prime}$ regions, transcribed in opposite directions) with the HSPB2 gene.

\section{Functional implications}

The relationship with sHSPs is not merely of evolutionary interest: $\alpha \mathrm{B}$-crystallin is a functional, stress-induced sHSP and is expressed in many tissues, notably muscle, sometimes at high levels (although not as high as in lens) [9]. In contrast, $\alpha$ A-crystallin is much more restricted to lens (although it has been found at low levels elsewhere, particularly in retina [16]) and may have evolved to specialize for the lens role, leaving the major sHSP role to $\alpha \mathrm{B}$-crystallin. This illustrates an evolutionary process in which a protein may acquire more than one role (for example, both sHSP and crystallin); if gene duplication then occurs, selection can lead to one or both copies of the gene specializing for one of the original functions [4].

A primary function of any crystallin is to contribute to the transparency and refractive power of the lens. However, other properties may also be important. In the case of the $\alpha$-crystallins, the chaperone-like functions of the sHSPs have clear implications for roles in preventing aggregation of misfolded proteins with obvious benefits to lens transparency [9]. They may also have important interactions with other cellular components, including cytoskeleton, which is of major importance in the highly elongated lens fiber cells [17].

Since CRYAB is now well known as a functional sHSP, there has been a tendency to extend this functionality to other crystallins when they are found in unexpected places. It is important to recognize that only CRYAA and $C R Y A B$ belong to the sHSP superfamily, and that functional roles for other crystallins are only slowly emerging.

\section{Cataractogenic mutations}

Several cataract-causing mutations have been identified in human $\alpha$-crystallins. For $C R Y A A$, three dominant cataractogenic mutations are known which involve substitution of one of two surface arginine residues: $\mathrm{R} 49 \mathrm{C}$
[18], R116C [19] and R116H [20]. Other mutants include a recessive nonsense mutation which essentially eliminates the ORF, W9X [21] and $\Delta \mathrm{Y} 118$ [22].

For $C R Y A B$, some dominant mutations cause cataract which is also associated with myofibrillar myopathy, reflecting the role of the gene in muscle [9]. Three of these involve truncations of the ORF: $\triangle 464 \mathrm{CT}$ [23], Q151X [23], and $\triangle 60 \mathrm{C}$ [24], while one other, R120G [25], involves substitution of a surface arginine. In contrast, another deletion/truncation mutation, $\triangle 450 \mathrm{~A}$, is only associated with posterior polar cataract [26]. Another congenital cataract in a Chinese study was identified with R69C [22].

\section{Genes for $\beta$ - and $\gamma$-crystallins Domains and exons}

These two families are evolutionarily related but are also distinct (Figure 3). They share common core protein structures, with two similar domains, each composed of two characteristic-modified Greek key motifs. $\beta$-crystallins may also have $\mathrm{N}$ - and/or $\mathrm{C}$-terminal extensions, exhibit greater structural flexibility in domain interactions, and form multimers, while $\gamma$-crystallins are strict monomers $[1,2,27]$. The two families also have distinct gene structures. In the genes for $\beta$-crystallins, each of the four structural motifs is encoded in a separate exon, while in (most) $\gamma$-crystallin genes, the 'intra-domain' introns are missing so that each domain is coded in a single exon (Figure 1). Genes for $\beta$-crystallin also have variable numbers of $5^{\prime}$ exons which account for $\mathrm{N}$-terminal protein extensions and which may include a non-coding first exon.

\section{CRYB genes}

This multigene family has ancient origins in vertebrates, and indeed the six human genes have clear orthologs in fish [28]. $\beta$-crystallins are subdivided into acidic (A) and basic (B) subunits, encoded in $C R Y B A(1,2,4)$ and $C R Y B B(1,2,3)$ genes. Unlike the $\alpha$-crystallins, four of the $\beta$-crystallin genes, arranged as two pairs, are close together on Chr 22 (Table 1, Figure 4).

\section{CRYBA1}

This single gene encodes two of the polypeptides that were originally identified by protein analysis of mammalian lenses, $\beta A 1$ - and $\beta A 3$-crystallins, through the use of alternative ORF start sites [29]. CRYBA1 is $7.6 \mathrm{~kb}$ long with six exons and is found on Chr 17, separated from other crystallin genes.

Cataractogenic mutations Inherited cataracts are surprisingly frequently associated with splicing defects at end of exon 3 in this gene that probably lead to exon skipping. These are IVS3+1G>A [30], IVS3+1 G>C [31], IVS3+1 G>T [32], and IVS3+2 T>G [33] with similar 


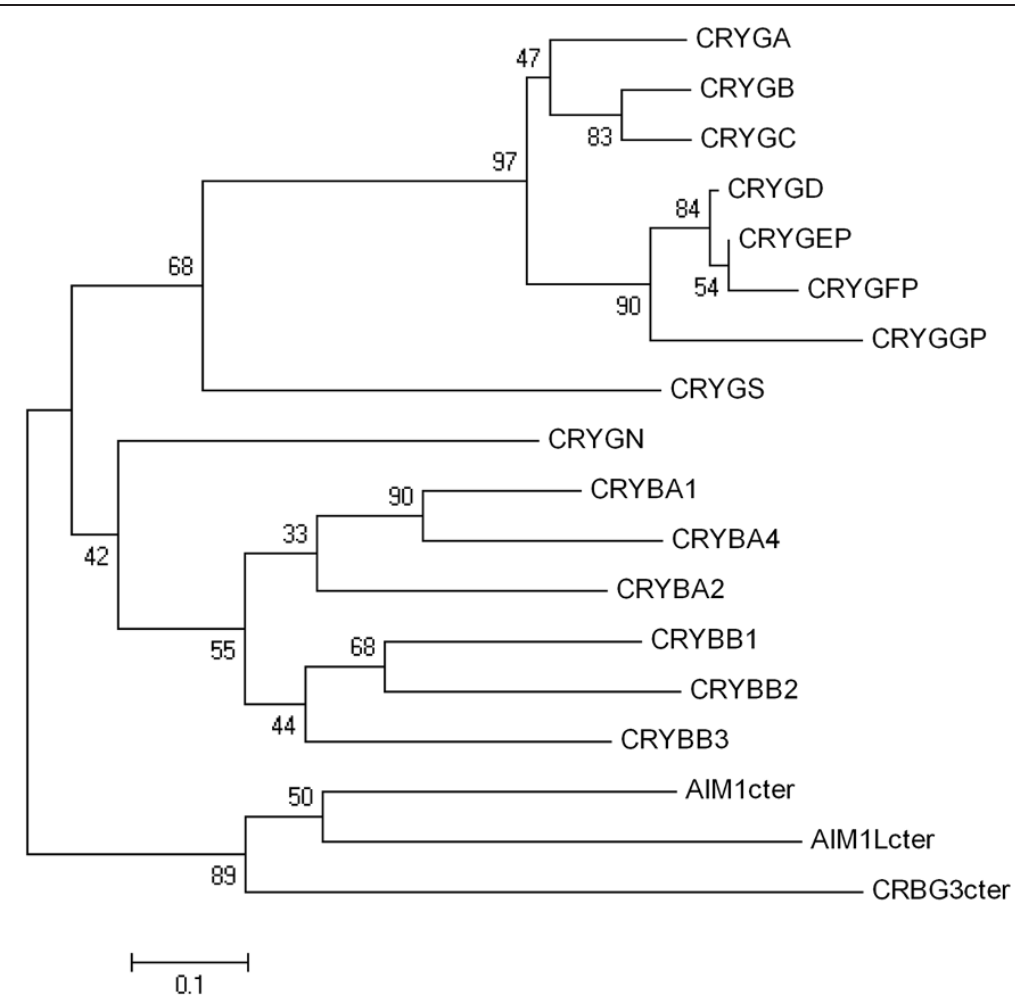

Figure 3 Phylogenetic tree of the human $\beta \gamma$-crystallin gene superfamily. Sequences were extracted from the UCSC web browser. Translated ORFs were aligned and neighbor-joining trees were constructed as in Figure 2. AIM1, AIML, and CRYBG3 contain internal repeats corresponding to three $\beta$-crystallin-like genes in addition to regions not related to crystallin genes. For simplicity, the third, most highly conserved crystallin repeat from each gene was used for this alignment (designated AlM1cter, etc.).

examples found in other families. Another mutation $(\triangle \mathrm{G} 91)$ is the result of a 3-bp deletion of the codon for a highly conserved glycine required for normal protein folding [34]. Work in mice has revealed a role for $\beta A 3 /$ A1-crystallin in retinal astrocyte function [35], but so far, it does not appear that astrocyte-related defects are associated with the human cataract mutations.

\section{CRYBA2}

This gene is also separated from other $\beta$-crystallin genes, being located on Chr 2, but is fairly close to a cluster of genes encoding $\gamma$-crystallins (Figure 4). The CRYBA2 gene is $3.2 \mathrm{~kb}$ long and the major form has five exons. A variant transcript in which the first intron is included is also represented by several cDNA clones; however, since the ORF starts in exon 2, there is no difference in predicted protein product. No human cataract mutants have yet been identified in this gene. Although cDNAs from this gene are abundant in an adult human lens cDNA library [36] for some time, it seemed that no protein for $\beta A 2-$ crystallin was expressed in human lens (in contrast to bovine and rodent lens in which the orthologous protein was quite abundant. Subsequently, human $\beta A 2$-crystallin was detected in the lens cortex but at relatively low levels [37], suggesting that translation of the mRNA may be inefficient.

\section{CRYBA4}

CRYBA4 is part of a cluster of $\beta$-crystallin genes that spans about $1.5 \mathrm{Mbp}$ on $\mathrm{Chr} 22$. The general organization of this cluster is conserved in several species, including chicken. This raises the possibility that linkage is maintained for functional reasons, perhaps for coordinated expression, but this has not been determined. Indeed, CRYBA4 is located head-to-head with $C R Y B B 1$ (transcribed in opposite directions), a linkage which is found in chicken [38] and is even present in zebrafish (Danio rerio). CRYBA4 has seven exons spread over $8.7 \mathrm{~kb}$.

Cataractogenic mutations Three coding sequence single-base transitions are associated with human cataracts. The F94S mutation gives rise to a dominant lamellar cataract [39]; L69P is associated with microphthalmia with cataract [39], and G64W is associated with congenital cataract and microcornea [40].

\section{CRYBB1}

The gene for $\beta B 1$-crystallin is an $18.6 \mathrm{~kb}$ gene with 6 exons, a structure common to all three of the genes for $\beta B$-crystallins and CRYBA4. 
Table 1 Human lens crystallin genes

\begin{tabular}{|c|c|}
\hline Crystallin genes & Chr \\
\hline \multicolumn{2}{|l|}{ a-crystallins } \\
\hline$C R Y A A / \mathrm{aA}$ & $21 q 22.3$ \\
\hline$C R Y A B / a B$ & $11 q 23.1$ \\
\hline \multicolumn{2}{|l|}{$\beta$-crystallins } \\
\hline$C R Y B A 1 / \beta A 1, \beta A 3$ & $17 q 11.2$ \\
\hline CRYBA2/BA2 & $2 q 35$ \\
\hline CRYBA4/ßA4 & $22 q 12.1$ \\
\hline CRYBB1/ßB1 & $22 q 12.1$ \\
\hline$C R Y B B 2 / \beta B 2$ & $22 q 11.3$ \\
\hline CRYBB2 P1 & $22 q 11.3$ \\
\hline CRYBB3/ßB3 & $22 q 11.23$ \\
\hline \multicolumn{2}{|l|}{$\gamma$-crystallins } \\
\hline$C R Y G A / Y A$ & $2 q 34$ \\
\hline$C R Y G B / Y B$ & $2 q 34$ \\
\hline$C R Y G C / \gamma C$ & $2 q 33.3$ \\
\hline$C R Y G D / \gamma D$ & $2 q 33.3$ \\
\hline$C R Y G E P / Y E$ & $2 q 33.3$ \\
\hline$C R Y G F P / Y F$ & $2 q 34$ \\
\hline$C R Y G S / \gamma S$ & $3 q 27.3$ \\
\hline CRYGN/YN & $7 q 36.1$ \\
\hline CRYGGP & $2 p 16.3$ \\
\hline \multicolumn{2}{|l|}{ 'Enyzme-crystallin' } \\
\hline$B H M T / \Psi$ & $5 q 14.1$ \\
\hline
\end{tabular}

Gene/protein names and chromosome locations are shown. Genes/proteins in bold type are expressed at relatively high levels similar to orthologs in other mammals. Those in normal type seem to have reduced or no expression in human lens. Some are designated pseudogenes. The proposed crystallin designation for betaine-homocysteine methyltransferase (BHMT), $\psi$, does not imply pseudogene status.

Cataractogenic mutations A variety of opacities and ocular development defects are associated with CRYBB1. Both dominant pulverulent (G220X) [41] and recessive nuclear $(\Delta \mathrm{G} 168)$ [42] cataracts have been associated with this gene. Autosomal dominant cataracts in
Chinese families are associated with Q223X [43], R233H [44], and S228P [45]. Other mutants, X253R [46] and S129R [47], are associated with both congenital cataract and microcornea.

\section{CRYBB2 and CRYBB2P1}

CRYBB2 is a $12.2 \mathrm{~kb}$, six-exon gene close to CRYBB3 in the Chr 22 cluster. There is a partial pseudogene copy CRYBB2P1 located about $250 \mathrm{~kb}$ away in the same cluster.

Cataractogenic mutations A nonsense mutation (Q155X) associated with dominant cerulean (blue and white opacities) cataract has been identified in several different populations [48-51]. It has been proposed that this mutation results from independent gene conversion events between CRYBB2 and CRYBB2P1 [50,51]. However, the close similarity of gene and pseudogene sequences also raises the possibility of mispriming or the generation of chimeras in genomic PCR. A recent note describes a lack of specificity in primer sets used to identify CRYBB2 mutants in another study [52,53], emphasizing the need for care in interpretation of results for this gene. Several other mutants have been reported including A2V (a surprisingly conservative change) [54], V146M and I21N [44], R188H [55] and S143F [56].

\section{CRYBB3}

$C R Y B B 3$ is located about $25 \mathrm{~kb} 5^{\prime}$ to $C R Y B B 2$ in the same orientation with no intervening genes. This linkage is conserved in chicken (where the separation is only about $2 \mathrm{~kb}$ ), but not in zebrafish. The gene is $7.5 \mathrm{~kb}$ long with six exons.

Cataractogenic mutations A recessive nuclear cataract is associated with a G165R mutation in CRYBB3 that likely interferes with normal folding of the protein [57].

Chromosome 2 cluste

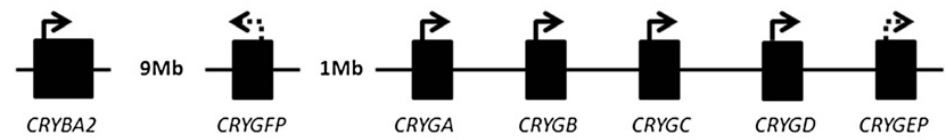

Chromosome 22 cluster

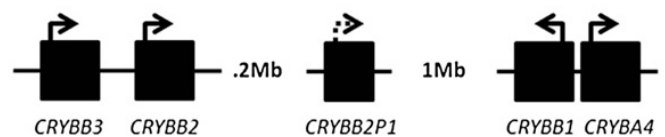

Figure 4 Clustering of crystallin genes. Gaps, indicated by approximate sizes, contain non-crystallin genes. Gene orientations are indicated with arrows (dotted for pseudogenes). 


\section{Genes for $\gamma$-crystallins}

In most mammals, there are eight genes for $\gamma$-crystallins $[1,2,28,58]$. Six encode a group of closely related proteins, $\gamma \mathrm{A}-\mathrm{F}$, that are typically expressed early in development and therefore contribute mainly to the densest, central region of the lens, the lens nucleus. The other two members of the family, $\gamma \mathrm{S}$ and $\gamma \mathrm{N}$, are more divergent in sequence, and their genes are located in different chromosomes (Table 1). All eight of these genes are expressed in the mouse lens; however, in humans, two of them are designated pseudogenes, another is effectively a pseudogene, and two others are expressed at relatively low levels in lens, suggesting that they too are in the process of evolutionary loss [28,59].

\section{CRYGA-CRYGFP}

These genes form a cluster in most mammals, and in the human genome, the orthologous genes and pseudogenes are clustered on Chr $2 \mathrm{q}$ (Figure 4). Unlike the $\beta$-crystallins, these $\gamma$-crystallins do not have orthologs in non-mammalian vertebrates; fish in particular have a large number of $\gamma \mathrm{M}$ proteins that do not group with the mammalian proteins in phylogenetic analysis [28]. $\gamma$-crystallins appear to be highly specialized for the dense packing of the lens nucleus and for the creation of high refractive index, relatively inflexible lenses. This probably explains the trend for loss of $\gamma$-crystallins in the accommodating lenses of primates, in birds, and in other species such as guinea pig (Cavia porcellus) [60].

The genes all have three exons (Figure 1) and are typically 2 to $4 \mathrm{~kb}$ in length. The cluster clearly arose by gene duplication. In humans, CRYGEP and CRYGFP are pseudogenes with no evidence of expression [57]. For this reason, they are not represented as genes in human genome builds or on most browsers. This is unfortunate since the genes are still largely intact and have at least the potential for involvement in gene conversion with active genes or even reactivation. Indeed, reactivation of CRYGEP was at one time considered as the basis for a human cataract, although this later proved not to be the case [61]. Five of the clustered CRYG genes are arranged sequentially: $C R Y G A, B, C, D$, and $E P$, within about 40 $\mathrm{kb}$ in the human genome (Figure 4). CRYGFP, despite its close similarity to CRYGEP, lies about $1 \mathrm{Mbp} 5^{\prime}$ to CRYGA.

CDNA and proteomics analyses show that most of the transcripts and proteins arising from this cluster in humans come only from CRYGC and CRYGD, with the latter being predominant $[36,62,63]$. This is reflected in known cataract mutations in $\gamma$-crystallin genes.

Cataractogenic mutations In $C R Y G C$, two mutations leading to single amino acid substitutions of surface residues, T5P [58] and R168P [64], and a frame-shifting 5 bp duplication in exon 2 (corresponding to the $\mathrm{N}$ terminal domain of the protein) [65], all cause cataract. In $C R Y G D$, five mutations leading to single amino acid substitutions, R14C [66], P23T [64,67], P23S [68], A35P [22], R36S [69], and R58H [58] and another causing truncation of the protein, W156X [64], give rise to several different forms of cataract.

\section{CRYGS}

This gene shares the three-exon structure of other $\gamma$-crystallin encoding genes; although at $6 \mathrm{~kb}$, it is somewhat larger than typical. Indeed, the longer, first intron of the human gene appears to contain a transcriptionally active region, of unknown function, and rare, probably non-functional, alternatively splice products of the gene that incorporate part of this sequence have been noted [70]. In contrast to the genes of the Chr 2 cluster, CRYGS is well-conserved in evolution and is expressed at high levels in human lens, particularly in adult in the cortical region $[36,70]$.

Cataractogenic mutations The distribution of expression in the lens is consistent with the progressive polymorphic cortical cataract caused by the G18V substitution of a key residue of the Greek-key motif [71]. Another mutant, D25G has also been reported [22].

\section{CRYGN}

This is another gene with orthologs throughout vertebrates [28]. Its gene structure resembles an evolutionary intermediate between those that code for the $\beta$ - and $\gamma$-crystallins, with the $\mathrm{N}$-terminal domain of the protein coded in one uninterrupted exon, as in a $\gamma$-crystallin gene, and the two motifs of the C-terminal domain encoded in separate exons, as in a $\beta$-crystallin gene (Figure 1). The gene is expressed at low levels in mouse lens and other parts of the eye [28], but human CRYGN appears to be non-functional. No cDNAs with the expected splice pattern for a full ORF have ever been detected, although some rare transcripts, apparently both sense and antisense, have been observed in different, non-lens cDNA libraries. These may relate to the presence of a microRNA gene, miR-3907, in the third intron of the gene. Human CRYGN is probably a pseudogene that has been deactivated relatively recently in evolution. However, the gene is represented in builds of the human genome and even has a RefSeq entry. The gene is $10 \mathrm{~kb}$ long and is located on Chr 7.

\section{CYRGGP}

In addition to the full-sized genes for $\gamma$-crystallins with orthologs in other mammals, the human genome contains an isolated fragment of sequence similar to that encoding $\gamma \mathrm{D}$ motif 2 in $C R Y G D$, apparently associated with 
a line located on Chr $2 \mathrm{p}$ [59]. This has been given a HUGO designation as CRYGGP, but it is not represented in most genome browsers. The name is problematic as it suggests that, by analogy to CRYGEP and CRYGFP, it is a formerly functional gene that has been silenced in the human lineage, whereas it appears to be merely a translocated remnant.

Superfamily relationships The $\beta \gamma$-crystallin superfamily contains many members in prokaryotes and eukaryotes. In the human genome, the major non-crystallin members of the superfamily are absent in melanoma 1 (AIM1) (also known as CRYBG1, for ' $\beta \gamma$ crystallin domain containing $1^{\prime}$ ), the related AIM1-like protein (AIMIL or CRYBG2) and CRYBG3. The proteins contain six $\beta \gamma$-crystallin-like domains encoded in exons arranged like those in $\beta$-crystallin genes [72,73]. Since the proteins encoded by these genes do not serve as crystallins, using the term to describe them is potentially confusing, at least from a functional point of view and the current nomenclature is inconsistent. The names AIM1, AIML1, and AIML2 would better describe their family relationship. However, there is potential confusion here too. The acronym 'AIM1' has been used for different genes (SLC45A2, AURKB), while AIM2 is the HGNC approved designation for another gene unrelated to AIM1.

AIM1 spans almost $60 \mathrm{~kb}$ on human Chr 6. It consists of 20 exons, 12 of which code for $\beta \gamma$-crystallin motifs, corresponding to six domains possibly arranged effectively as a $\beta$-crystallin trimer [72]. Additional short exons in this region code for linkers between the two-domain $\beta$-crystallin regions. This region must have arisen by successive duplication of an ancestral, $\beta$-crystallin-like gene. The AIM1 protein also contains a long, prolinerich $\mathrm{N}$-terminal region (over 1,000 residues) with no clear structural relationships and a $\mathrm{C}$-terminal ricin-like trefoil domain. Interestingly, another connection between $\beta \gamma$ domains and a trefoil domain has been observed in a protein discovered in skin secretions of a frog (Bombina maxima). The so-called $\beta \gamma$-CAT [74] is a dimer of a $\beta \gamma$-crystallin superfamily member and a trefoil domain protein. Although AIM1 is not a crystallin, it is expressed at moderately high levels in a human cornea cDNA library [75].

The AIM1L gene covers $32 \mathrm{~kb}$ on Chr 1, and CRYBG3 covers $123 \mathrm{~kb}$ on Chr 3 . Both these genes have similar exon/domain structures to AIM1, although CRYBG3 appears to have two additional coding $5^{\prime}$ exons.

Functional implications Members of the $\beta \gamma$-crystallin superfamily are quite diverse, and no single functional role is clear. However, some of them seem to be associated with cellular architecture. AIM1 expression is associated with changes in appearance and reduction of malignancy in melanoma cells [76], while another relative, EDSP/Ep36, is associated with plasma membrane in developing Cynops amphibian embryos [77,78]. Recently, it has been shown that mouse $\gamma \mathrm{S}$-crystallin associates with F-actin in the lens and can stabilize F-actin in vitro [79]. While not reaching the level of chaperone activity, it is possible that the characteristic $\beta \gamma$-crystallin protein domain has a generalized role in shepherding large oligomers (like cytoskeleton and other crystallins) and preventing aggregation.

\section{BHMT and other 'enzyme crystallins'}

As described above, some major crystallins are more or less specialized for their role in lens and may have no role, or at least only a minor role, in other tissues. However, during evolution, the molecular composition of the lens has adapted in response to changing environmental demands. In the human lineage, this has involved the loss of $\gamma$-crystallins, the loss of the alternative 'insert' exon of CRYAA, and (probably) decreased expression of $C R Y B A 2$, while genes for other non-crystallin proteins, such as LGSN/lengsin (exon loss) [80] and LIM2/MP19 (exon extension) [36], have also been affected. In many species, particularly when expression of $\gamma$-crystallins has been reduced, existing, stable proteins with the needed properties have been recruited to a new role as a crystallin through increased expression in lens. These are usually enzymes, so that, for example, in many birds and crocodiles the enzyme lactate dehydrogenase B became $\varepsilon$-crystallin in the lens while retaining its expression and function as an enzyme [81]. The same process has occurred in primates. Probably to compensate for, or to replace absent or down-regulated $\gamma$-crystallins, the developing primate lens expresses high levels of the enzyme BHMT [82]. In a human fetal lens cDNA library, $B H M T$ is the most abundantly expressed gene (http://neibank.nei.nih.gov/cgi-bin/showDataTable.cgi?

lib=NbLib0012). Thus, BHMT should certainly qualify as a human crystallin gene; however, the proposed name $\psi$-crystallin [82] has not been widely used perhaps because of the potential confusion with the symbol for pseudogene. So far, no genetic cataract has been associated with $B H M T / \psi$-crystallin, but it is certainly a candidate worth considering for congenital nuclear cataract, possibly microphthalmia. BHMT, as expressed in many tissues, is an eight exon, 20-kb gene on Chr 5 separated by about $20 \mathrm{~kb}$ from the related BHMT2.

The term crystallin may also arise in connection with other human genes whose orthologs in other species serve as crystallins. CRYM is the human ortholog of the gene that encodes $\mu$-crystallin in many marsupials [83-85]. In humans, CRYM is expressed quite abundantly in retina and inner ear, where mutants are associated with deafness [86], and cDNAs for this gene are found 
in libraries from retina and fetal eye; however, it does not rise to 'crystallin-levels' of expression in lens. $\mu$-crystallin belongs to an enzyme superfamily and has been identified as a ketamine reductase and also as a thyroid-hormone-binding protein $[84,87,88]$.

$C R Y Z$ is the human ortholog of the gene that codes for $\zeta$-crystallin in hystricomorph rodents (such as guinea pig) and camels [89]. The protein is a quinone oxidoreductase [90]which is not expressed at high levels in human lens, although it is moderately abundant in a human cornea cDNA library [75]. A related gene is designated as CRYZL1, and there is also a pseudogene copy, CRYZP1.

$C R Y L$ is the human ortholog of the gene that codes for $\lambda$-crystallin in lagomorphs (rabbits, hares, pikas) [91]. $\lambda$-crystallin is related to hydroxyacyl coenzyme A dehydrogenases but does not serve as a crystallin in humans.

The enzyme $\alpha$-enolase (ENO1) is also sometimes referred to as $\tau$-crystallin (see OMIM: *172430) because of its role as a crystallin in several non-mammalian species [92], but, although quite abundant as an enzyme in lens, it does not pass the (rather subjective) test to qualify as a human crystallin.

\section{Lens-preferred gene expression}

Although proteins of very different superfamilies act as crystallins in the lens, they all acquired this role through increased gene expression in the lens. Some crystallins are essentially tissue-specific, most have some level of expression in other parts of the eye, while others have a completely separate machinery of expression in nonocular tissues. The basis for lens-expression is similar for many, if not all, crystallins. The gene promoter contains response elements for some key transcription factors essential for normal lens development. Prominent among these are factors such as Pax6, c-Maf, Sox2, Prox1, and Six3 $[93,94]$. In many crystallin gene promoters, elements for lens and non-lens expression are combined in the same $5^{\prime}$ region. However, one of the more recently recruited enzyme crystallins, $\zeta$-crystallin of the guinea pig (C. porcellus), illustrates dual promoter functionality quite nicely with an alternative promoter dependent on Pax6 and Maf elements, driving lensspecific expression [95].

\section{Conclusion}

The human genome contains genes corresponding to all the major crystallins that are expressed in mouse and most other mammals. However, some of these (CRYGEP, CRYGFP, and CRYGN) are designated or likely pseudogenes in humans, while other genes have reduced expression compared with mouse. The genes for human crystallins encode proteins which belong to two unrelated superfamilies, the $\alpha$-crystallin/sHSP superfamily and the $\beta \gamma$-crystallin superfamily (which in the human genome contains three genes for the AIM1 family). Ancestral members of these superfamilies were recruited to serve as crystallins in the earliest vertebrate lens, presumably because they could form and maintain the transparent, refractive medium needed to focus light. Humans also have another gene that has been recruited to a crystallin role more recently in evolution. The enzyme BHMT has very high expression in fetal lens where it may serve to replace those $\gamma$-crystallins whose expression has been reduced or eliminated. Indeed, crystallins have provided important early insights into the ways proteins can have multiple functions and can be adapted during evolution [4]. As might be expected, crystallins are implicated in many inherited cataracts, but in addition, due to their other roles as stress proteins or enzymes, proteins that serve as crystallins also show up unexpectedly in a number of disease states in eye and other tissues.

\section{Competing interests}

The author has no competing interests.

Received: 12 September 2012 Accepted: 25 October 2012 Published: 1 December 2012

\section{References}

1. Wistow G, Slingsby C: Structure and evolution of crystallins. The Encyclopedia of the Eye 2010, 2:229-238.

2. Bloemendal H, De Jong W, Jaenicke R, Lubsen NH, Slingsby C, Tardieu A: Ageing and vision: structure, stability and function of lens crystallins. Prog Biophys Mol Biol 2004, 86:407-485.

3. Harding JJ, Crabbe MJC: The lens: development, proteins, metabolism and cataract. Eye 1984, 1B:207-492.

4. Wistow G: Lens crystallins: gene recruitment and evolutionary dynamism. Trends Biochem Sci 1993, 18:301-306.

5. Piatigorsky J: Review: a case for corneal crystallins. J Ocul Pharmacol Ther 2000, 16:173-180.

6. Lassen N, Black WJ, Estey T, Vasiliou V: The role of corneal crystallins in the cellular defense mechanisms against oxidative stress. Semin Cell Dev Biol 2008, 19:100-112.

7. Jester JV: Corneal crystallins and the development of cellular transparency. Semin Cell Dev Biol 2008, 19:82-93.

8. Wistow G, Peterson K, Gao J, Buchoff P, Jaworski C, Bowes-Rickman C, Ebright JN, Hauser MA, Hoover D: NEIBank: genomics and bioinformatics resources for vision research. Mol Vis 2008, 14:1327-1337.

9. Clark AR, Lubsen NH, Slingsby C: sHSP in the eye lens: crystallin mutations, cataract and proteostasis. Int J Biochem Cell Biol 2012, 44:1687-1697.

10. van Dijk MA, Sweers MA, de Jong WW: The evolution of an alternatively spliced exon in the alphaA-crystallin gene. J Mol Evol 2001, 52:510-515.

11. Jaworski CJ, Piatigorsky J: A pseudo-exon in the functional human alphaA-crystallin gene. Nature 1989, 337:752-754.

12. de Jong WW, Caspers GJ, Leunissen JA: Genealogy of the alphacrystallin-small heat-shock protein superfamily. Int J Biol Macromol 1998, 22:151-162.

13. Fontaine JM, Rest JS, Welsh MJ, Benndorf R: The sperm outer dense fiber protein is the 10th member of the superfamily of mammalian small stress proteins. Cell Stress Chaperones 2003, 8:62-69.

14. Kappe G, Boelens WC, de Jong WW: Why proteins without an alphacrystallin domain should not be included in the human small heat shock protein family HSPB. Cell Stress Chaperones 2010, 15:457-461.

15. Tamura K, Dudley J, Nei M, Kumar S: MEGA4: Molecular Evolutionary Genetics Analysis (MEGA) software version 4.0. Mol Biol Evol 2007, 24:1596-1599. 
16. Rao NA, Saraswathy S, Pararajasegaram G, Bhat SP: Small heat shock protein alphaA-crystallin prevents photoreceptor degeneration in experimental autoimmune uveitis. PLoS One 2012, 7:e33582.

17. Quinlan R: Cytoskeletal competence requires protein chaperones. Prog Mol Subcell Biol 2002, 28:219-233.

18. Mackay DS, Andley UP, Shiels A: Cell death triggered by a novel mutation in the alphaA-crystallin gene underlies autosomal dominant cataract linked to chromosome 21q. Eur J Hum Genet 2003, 11:784-793.

19. Litt M, Kramer P, LaMorticella DM, Murphey W, Lovrien EW, Weleber RG: Autosomal dominant congenital cataract associated with a missense mutation in the human alpha crystallin gene CRYAA. Hum Mol Genet 1998, 7:471-474.

20. Richter L, Flodman P, Barria von-Bischhoffshausen F, Burch D, Brown S, Nguyen L, Turner J, Spence MA, Bateman JB: Clinical variability of autosomal dominant cataract, microcornea and corneal opacity and novel mutation in the alpha A crystallin gene (CRYAA). Am J Med Genet $A$ 2008, 146:833-842.

21. Pras E, Frydman M, Levy-Nissenbaum E, Bakhan T, Raz J, Assia El, Goldman $\mathrm{B}$ : A nonsense mutation (W9X) in CRYAA causes autosomal recessive cataract in an inbred Jewish Persian family. Invest Ophthalmol Vis Sci 2000, 41:3511-3515

22. Sun W, Xiao X, Li S, Guo X, Zhang Q: Mutation analysis of 12 genes in Chinese families with congenital cataracts. Mol Vis 2011, 17:2197-2206.

23. Selcen D, Engel AG: Myofibrillar myopathy caused by novel dominant negative alpha B-crystallin mutations. Ann Neurol 2003, 54:804-810.

24. Del Bigio MR, Chudley AE, Sarnat HB, Campbell C, Goobie S, Chodirker BN, Selcen D: Infantile muscular dystrophy in Canadian aboriginals is an alphaB-crystallinopathy. Ann Neurol 2011, 69:866-871.

25. Vicart P, Caron A, Guicheney P, Li Z, Prevost MC, Faure A, Chateau D, Chapon F, Tome F, Dupret JM, Paulin D, Fardeau M: A missense mutation in the alphaB-crystallin chaperone gene causes a desmin-related myopathy. Nat Genet 1998, 20:92-95.

26. Berry V, Francis P, Reddy MA, Collyer D, Vithana E, Mackay I, Dawson G, Carey AH, Moore A, Bhattacharya SS, Quinlan RA: Alpha-B crystallin gene (CRYAB) mutation causes dominant congenital posterior polar cataract in humans. Am J Hum Genet 2001, 69:1141-1145.

27. Wistow GJ, Piatigorsky J: Lens crystallins: the evolution and expression of proteins for a highly specialized tissue. Annu Rev Biochem 1988, 57:479-504.

28. Wistow G, Wyatt K, David L, Gao C, Bateman O, Bernstein S, Tomarev S, Segovia L, Slingsby C, Vihtelic T: gammaN-crystallin and the evolution of the betagamma-crystallin superfamily in vertebrates. FEBS J 2005, 272:2276-2291

29. Hogg D, Tsui LC, Gorin M, Breitman ML: Characterization of the human beta-crystallin gene $\mathrm{Hu}$ beta $\mathrm{A} 3 / \mathrm{A} 1$ reveals ancestral relationships among the beta gamma-crystallin superfamily. J Biol Chem 1986, 261:12420-12427.

30. Kannabiran C, Rogan PK, Olmos L, Basti S, Rao GN, Kaiser-Kupfer M, Hejtmancik JF: Autosomal dominant zonular cataract with sutural opacities is associated with a splice mutation in the betaA3/A1-crystallin gene. Mol Vis 1998, 4:21.

31. Bateman JB, Geyer DD, Flodman P, Johannes M, Sikela J, Walter N, Moreira AT, Clancy K, Spence MA: A new betaA1-crystallin splice junction mutation in autosomal dominant cataract. Invest Ophthalmol Vis Sci 2000 , 41:3278-3285

32. Yang Z, Li Q, Ma Z, Guo Y, Zhu S, Ma X: A G->T splice site mutation of CRYBA1/A3 associated with autosomal dominant suture cataracts in a Chinese family. Mol Vis 2011, 17:2065-2071.

33. Yang Z, Su D, Li Q, Yang F, Ma Z, Zhu S, Ma X: A novel T->G splice site mutation of CRYBA1/A3 associated with autosomal dominant nuclear cataracts in a Chinese family. Mol Vis 2012, 18:1283-1288.

34. Qi Y, Jia H, Huang S, Lin H, Gu J, Su H, Zhang T, Gao Y, Qu L, Li D, Li Y: A deletion mutation in the betaA1/A3 crystallin gene (CRYBA1/A3) is associated with autosomal dominant congenital nuclear cataract in a Chinese family. Hum Genet 2004, 114:192-197.

35. Sinha D, Valapala M, Bhutto I, Patek B, Zhang C, Hose S, Yang F, Cano M, Stark WJ, Lutty GA, Zigler JS, Wawrousek EF: betaA3/A1-crystallin is required for proper astrocyte template formation and vascular remodeling in the retina. Transgenic Res 2012, 21:1033-1042.

36. Wistow G, Bernstein SL, Wyatt MK, Behal A, Touchman JW, Bouffard G, Smith D, Peterson K: Expressed sequence tag analysis of adult human lens for the NEIBank Project: over 2000 non-redundant transcripts, novel genes and splice variants. Mol Vis 2002, 8:171-184.

37. Lapko VN, Smith DL, Smith JB: Expression of betaA2-crystallin in human lenses. Exp Eye Res 2003, 77:383-385.

38. Duncan MK, Haynes Jl, Piatigorsky J: The chicken betaA4- and betaB1crystallin-encoding genes are tightly linked. Gene 1995, 62:189-196.

39. Billingsley G, Santhiya ST, Paterson AD, Ogata K, Wodak S, Hosseini SM, Manisastry SM, Vijayalakshmi P, Gopinath PM, Graw J, Heon E: CRYBA4, a novel human cataract gene is also involved in microphthalmia. Am J Hum Genet 2006, 79:702-709.

40. Zhou G, Zhou N, Hu S, Zhao L, Zhang C, Qi Y: A missense mutation in CRYBA4 associated with congenital cataract and microcornea. Mol Vis 2010, 16:1019-1024.

41. Mackay DS, Boskovska OB, Knopf HL, Lampi KJ, Shiels A: A nonsense mutation in CRYBB1 associated with autosomal dominant cataract linked to human chromosome 22q. Am J Hum Genet 2002, 71:1216-1221.

42. Cohen D, Bar-Yosef U, Levy J, Gradstein L, Belfair N, Ofir R, Joshua S, Lifshitz T, Carmi R, Birk OS: Homozygous CRYBB1 deletion mutation underlies autosomal recessive congenital cataract. Invest Ophthalmol Vis Sci 2007, 48:2208-2213

43. Yang J, Zhu Y, Gu F, He X, Cao Z, Li X, Tong Y, Ma X: A novel nonsense mutation in CRYBB1 associated with autosomal dominant congenital cataract. Mol Vis 2008, 14:727-731.

44. Wang KJ, Wang BB, Zhang F, Zhao Y, Ma X, Zhu SQ: Novel beta-crystallin gene mutations in Chinese families with nuclear cataracts. Arch Ophthalmol 2011, 129:337-343.

45. Wang J, Ma X, Gu F, Liu NP, Hao XL, Wang KJ, Wang NL, Zhu SQ: A missense mutation S228P in the CRYBB1 gene causes autosomal dominant congenital cataract. Chin Med J (Engl) 2007, 120:820-824.

46. Willoughby CE, Shafiq A, Ferrini W, Chan LL, Billingsley G, Priston M, Mok C, Chandna A, Kaye S, Heon E: CRYBB1 mutation associated with congenital cataract and microcornea. Mol Vis 2005, 11:587-593.

47. Wang KJ, Wang S, Cao NQ, Yan YB, Zhu SQ: A novel mutation in CRYBB1 associated with congenital cataract-microcornea syndrome: the $\mathrm{p}$. Ser129Arg mutation destabilizes the betaB1/betaA3-crystallin heteromer but not the betaB1-crystallin homomer. Hum Mutat 2011, 32:E2050-E2060

48. Litt M, Carrero-Valenzuela R, LaMorticella DM, Schultz DW, Mitchell TN, Kramer $\mathrm{P}$, Maumenee $\mathrm{H}$ : Autosomal dominant cerulean cataract is associated with a chain termination mutation in the human betacrystallin gene CRYBB2. Hum Mol Genet 1997, 6:665-668.

49. Gill D, Klose R, Munier FL, McFadden M, Priston M, Billingsley G, Ducrey N, Schorderet DF, Heon E: Genetic heterogeneity of the Coppock-like cataract: a mutation in CRYBB2 on chromosome 22q11.2. Invest Ophthalmol Vis Sci 2000, 41:159-165.

50. Vanita, Sarhadi V, Reis A, Jung M, Singh D, Sperling K, Singh JR, Burger J: A unique form of autosomal dominant cataract explained by gene conversion between beta-crystallin B2 and its pseudogene. J Med Genet 2001, 38:392-396.

51. Bateman JB, von-Bischhoffshaunsen FR, Richter L, Flodman P, Burch D, Spence M: Gene conversion mutation in crystallin, beta-B2 (CRYBB2) in a Chilean family with autosomal dominant cataract. Ophthalmology 2007, 114:425-432.

52. Kumar KD, Kumar GS, Santhiya ST: Nonspecific PCR amplification of CRYBB2-pseudogene leads to misconception of natural variation as mutation. Investig Ophthalmol Vis Sci 2012, 53:5770.

53. Hansen L, Mikkelsen A, Nurnberg P, Nurnberg G, Anjum I, Eiberg H, Rosenberg T: Comprehensive mutational screening in a cohort of Danish families with hereditary congenital cataract. Invest Ophthalmol Vis Sci 2009, 50:3291-3303.

54. Yao K, Li J, Jin C, Wang W, Zhu Y, Shentu X, Wang Q: Characterization of a novel mutation in the CRYBB2 gene associated with autosomal dominant congenital posterior subcapsular cataract in a Chinese family. Mol Vis 2011, 17:144-152.

55. Weisschuh N, Aisenbrey S, Wissinger B, Riess A: Identification of a novel CRYBB2 missense mutation causing congenital autosomal dominant cataract. Mol Vis 2012, 18:174-180.

56. Faletra F, d'Adamo AP, Pensiero S, Athanasakis E, Catalano D, Bruno I, Gasparini P: A novel CRYBB2 missense mutation causing Congenital autosomal dominant cataract in an Italian family. Ophthalmic Genet, in press. 
57. Riazuddin SA, Yasmeen A, Yao W, Sergeev YV, Zhang Q, Zulfiqar F, Riaz A, Riazuddin S, Hejtmancik JF: Mutations in betaB3-crystallin associated with autosomal recessive cataract in two Pakistani families. Invest Ophthalmol Vis Sci 2005, 46:2100-2106.

58. Heon E, Priston M, Schorderet DF, Billingsley GD, Girard PO, Lubsen N, Munier FL: The gamma-crystallins and human cataracts: a puzzle made clearer. Am J Hum Genet 1999, 65:1261-1267.

59. Brakenhoff RH, Aarts HJ, Reek FH, Lubsen NH, Schoenmakers JG: Human gamma-crystallin genes. A gene family on its way to extinction. $J \mathrm{Mol}$ Biol 1990, 216:519-532.

60. Simpanya MF, Wistow G, Gao J, David LL, Giblin FJ, Mitton KP: Expressed sequence tag analysis of guinea pig (Cavia porcellus) eye tissues for NEIBank. Mol Vis 2008, 14:2413-2427.

61. Brakenhoff $\mathrm{RH}$, Henskens HAM, van Rossum MWPC, Lubsen NH, Schoenmakers JGG: Activation of the gammaE-crystallin pseudogene in the human hereditary Coppock-like cataract. Hum Mol Genet 1994, 3:279-283.

62. Robinson NE, Lampi KJ, Speir JP, Kruppa G, Easterling M, Robinson AB: Quantitative measurement of young human eye lens crystallins by direct injection Fourier transform ion cyclotron resonance mass spectrometry. Mol Vis 2006, 12:704-711.

63. Lapko VN, Smith DL, Smith JB: Methylation and carbamylation of human gamma-crystallins. Protein Sci 2003, 12:1762-1774.

64. Santhiya ST, Shyam Manohar M, Rawlley D, Vijayalakshmi P, Namperumalsamy P, Gopinath PM, Loster J, Graw J: Novel mutations in the gamma-crystallin genes cause autosomal dominant congenital cataracts. J Med Genet 2002, 39:352-358.

65. Ren Z, Li A, Shastry BS, Padma T, Ayyagari R, Scott MH, Parks MM, Kaiser-Kupfer MI, Hejtmancik JF: A 5-base insertion in the gammaCcrystallin gene is associated with autosomal dominant variable zonular pulverulent cataract. Hum Genet 2000, 106:531-537.

66. Stephan DA, Gillanders E, Vanderveen D, Freas-Lutz D, Wistow G, Baxevanis AD, Robbins CM, VanAuken A, Quesenberry Ml, Bailey-Wilson J, Juo SH, Trent JM, Smith L, Brownstein MJ: Progressive juvenile-onset punctate cataracts caused by mutation of the gammaD-crystallin gene. Proc Natl Acad Sci USA 1999, 96:1008-1012.

67. Nandrot E, Slingsby C, Basak A, Cherif-Chefchaouni M, Benazzouz B, Hajaji Y, Boutayeb S, Gribouval O, Arbogast L, Berraho A, Abitbol M, Hilal L: Gamma-D crystallin gene (CRYGD) mutation causes autosomal dominant congenital cerulean cataracts. J Med Genet 2003, 40:262-267.

68. Plotnikova OV, Kondrashov FA, Vlasov PK, Grigorenko AP, Ginter EK, Rogaev El: Conversion and compensatory evolution of the gammacrystallin genes and identification of a cataractogenic mutation that reverses the sequence of the human CRYGD gene to an ancestral state. Am J Hum Genet 2007, 81:32-43.

69. Kmoch S, Brynda J, Asfaw B, Bezouska K, Novak P, Rezacova P, Ondrova L, Filipec M, Sedlacek J, Elleder M: Link between a novel human gammaDcrystallin allele and a unique cataract phenotype explained by protein crystallography. Hum Mol Genet 2000, 9:1779-1786.

70. Wistow G, Sardarian L, Gan W, Wyatt MK: The human gene for gammaScrystallin: alternative transcripts and expressed sequences from the first intron. Mol Vis 2000, 6:79-84.

71. Sun H, Ma Z, Li Y, Liu B, Li Z, Ding X, Gao Y, Ma W, Tang X, Li X, Shen Y: Gamma-S crystallin gene (CRYGS) mutation causes dominant progressive cortical cataract in humans. J Med Genet 2005, 42:706-710.

72. Ray ME, Wistow G, Su YA, Meltzer PS, Trent JM: AIM1, a novel non-lens member of the betagamma-crystallin superfamily is associated with the control of tumorigenicity in human malignant melanoma. Proc Natl Acad Sci USA 1997, 94:3229-3234.

73. Aravind $P$, Wistow $G$, Sharma $Y$, Sankaranarayanan R: Exploring the limits of sequence and structure in a variant betagamma-crystallin domain of the protein absent in melanoma-1 (AIM1). J Mol Biol 2008, 381:509-518.

74. Liu SB, He YY, Zhang Y, Lee WH, Qian JQ, Lai R, Jin Y: A novel non-lens betagamma-crystallin and trefoil factor complex from amphibian skin and its functional implications. PLoS One 2008, 3:e1770.

75. Rabinowitz YS, Dong L, Wistow G: Gene expression profile studies of human keratoconus cornea for NEIBank: a novel cornea expressed gene and the absence of transcripts for aquaporin 5. Invest Ophthalmol Vis Sci 2005, 46:1239-1246.

76. Ray ME, Su YA, Meltzer PS, Trent JM: Isolation and characterization of genes associated with chromosome- 6 mediated tumor suppression in human malignant melanoma. Oncogene 1996, 12:2527-2533.
77. Wistow G, Jaworski C, Rao PV: A non-lens member of the beta gammacrystallin superfamily in a vertebrate the amphibian Cynops. Exp Eye Res 1995, 61:637-639.

78. Takabatake T, Takahashi TC, Takeshima K: Cloning of an epidermis-specific Cynops CDNA from a neurula library. Develop Growth Differ 1992, 34:277-283.

79. Fan J, Dong L, Mishra S, Chen Y, Fitzgerald P, Wistow G: A role for gammaS-crystallin in the organization of actin and fiber cell maturation in the mouse lens. FEBS J 2012, 279:2892-2904.

80. Wyatt K, White HE, Wang L, Bateman OA, Slingsby C, Orlova EV, Wistow G: Lengsin is a survivor of an ancient family of class I glutamine synthetases re-engineered by evolution for a role in the vertebrate lens. Structure 2006, 14:1823-1834.

81. Wistow GJ, Mulders JW, de Jong WW: The enzyme lactate dehydrogenase as a structural protein in avian and crocodilian lenses. Nature 1987. 326:622-624.

82. Rao PV, Garrow TA, John F, Garland D, Millian NS, Zigler JS Jr: Betainehomocysteine methyltransferase is a developmentally regulated enzyme crystallin in rhesus monkey lens. J Biol Chem 1998, 273:30669-30674.

83. Wistow $\mathrm{G}$, Kim H: Lens protein expression in mammals: taxon-specificity and the recruitment of crystallins. J Mol Evol 1991, 32:262-269.

84. Kim RY, Gasser R, Wistow GJ: Mu-crystallin is a mammalian homologue of Agrobacterium ornithine cyclodeaminase and is expressed in human retina. Proc Natl Acad Sci USA 1992, 89:9292-9296.

85. Segovia L, Horwitz J, Gasser R, Wistow G: Two roles for mu-crystallin: a lens structural protein in diurnal marsupials and a possible enzyme in mammalian retinas. Mol Vis 1997, 3:9.

86. Abe S, Katagiri T, Saito-Hisaminato A, Usami S, Inoue Y, Tsunoda T, Nakamura Y: Identification of CRYM as a candidate responsible for nonsyndromic deafness through cDNA microarray analysis of human cochlear and vestibular tissues. Am J Hum Genet 2003, 72:73-82.

87. Hallen A, Cooper AJ, Jamie JF, Haynes PA, Willows RD: Mammalian forebrain ketimine reductase identified as mu-crystallin; potential regulation by thyroid hormones. J Neurochem 2011, 118:379-387.

88. Vie MP, Evrard C, Osty J, Breton-Gilet A, Blanchet P, Pomerance M, Rouget $P$, Francon J, Blondeau JP: Purification, molecular cloning, and functional expression of the human nicodinamide-adenine dinucleotide phosphate-regulated thyroid hormone-binding protein. Mol Endocrinol 1997, 11:1728-1736

89. Gonzalez P, Rao PV, Nunez SB, Zigler JS Jr: Evidence for independent recruitment of zeta-crystallin/quinone reductase (CRYZ) as a crystallin in camelids and hystricomorph rodents. Mol Biol Evol 1995, 12:773-781.

90. Rao PV, Krishna CM, Zigler JS: Identification and characterization of the enzymatic activity of zeta-crystallin from guinea pig lens. A novel NADPH:quinone oxidoreductase. J Biol Chem 1992, 267:96-102.

91. Mulders JW, Hendriks W, Blankesteijn WM, Bloemendal H, de Jong WW: Lambda-crystallin, a major rabbit lens protein, is related to hydroxyacylcoenzyme A dehydrogenases. J Biol Chem 1988, 263:15462-15466.

92. Wistow GJ, Lietman T, Williams LA, Stapel SO, de Jong WW, Horwitz J, Piatigorsky J: Tau-crystallin/alpha-enolase: one gene encodes both an enzyme and a lens structural protein. J Cell Biol 1988, 107:2729-2736.

93. Cvekl A, Yang Y, Chauhan BK, Cveklova K: Regulation of gene expression by Pax6 in ocular cells: a case of tissue-preferred expression of crystallins in lens. Int J Dev Biol 2004, 48:829-844.

94. Cvekl A, Duncan MK: Genetic and epigenetic mechanisms of gene regulation during lens development. Prog Retin Eye Res 2007, 26:555-597.

95. Sharon-Friling R, Richardson J, Sperbeck S, Lee D, Rauchman M, Maas R, Swaroop A, Wistow G: Lens-specific gene recruitment of zeta-crystallin through Pax6 Nrl-Maf, and brain suppressor sites. Mol Cell Biol 1998, 18:2067-2076

doi:10.1186/1479-7364-6-26

Cite this article as: Wistow: The human crystallin gene families. Human Genomics 2012 6:26. 